\title{
Effect of Culture Conditions on the Production of an Extracellular Protease by Bacillus sp. Isolated from Soil Sample of Lavizan Jungle Park
}

\author{
Abbas Akhavan Sepahy ${ }^{1}$ and Leila Jabalameli² \\ ${ }^{1}$ Department of Microbiology, North Tehran Branch of Islamic Azad University, 1667934791 Tehran, Iran \\ ${ }^{2}$ Department of Biology, Science and Research Branch of Islamic Azad University, 1477893855 Tehran, Iran
}

Correspondence should be addressed to Abbas Akhavan Sepahy, akhavansepahy@gmail.com

Received 5 May 2011; Revised 16 July 2011; Accepted 15 September 2011

Academic Editor: Alane Beatriz Vermelho

Copyright ( 2011 A. Akhavan Sepahy and L. Jabalameli. This is an open access article distributed under the Creative Commons Attribution License, which permits unrestricted use, distribution, and reproduction in any medium, provided the original work is properly cited.

\begin{abstract}
Soil samples of Tehran jungle parks were screened for proteolytic Bacilli. Among eighteen protease producers one of the isolates obtained from Lavizan park, in north east of Tehran, was selected for further experimental studies. This isolate was identified as Bacillus sp. strain CR-179 based on partial sequencing of 16S rRNA. Various nutritional and environmental parameters affected protease production by Bacillus sp. strain CR-179. Protease production by this Bacillus cultivated in liquid cultures reached a maximum at $24 \mathrm{~h}$, with levels of $340.908 \mathrm{U} / \mathrm{mL}$. Starch and maltose were the best substrates for enzyme production while some pure sugars such as fructose, glucose, and sucrose could not influence production of protease. Among various organic nitrogen sources corn steep liquor, which is commercial, was found as the best substrate followed by yeast extract, whey protein, and beef extract. The optimal $\mathrm{pH}$ and optimal temperature of enzyme production were 8.0 and $45^{\circ} \mathrm{C}$, respectively. Studies on enzymatic characterization revealed that crude protease showed maximum activity at $\mathrm{pH} 9.0$ and $60^{\circ} \mathrm{C}$, which is indicating the enzyme to be thermoalkaline protease.
\end{abstract}

\section{Introduction}

Proteases are one of the most important industrial enzymes and are used in a variety of industrial applications, such as laundry detergents, pharmaceutical industry, leather industry in dehairing and bating of hides, manufacture of protein hydrolyzates, food industry like meat tenderizing, cheese flavour development, treatment of flour in the manufacture of baked goods, improvement of dough texture, flavour and colour in cookies, and so forth [1-6], silver recovery from X-ray films [7], and even in waste processing industry $[8,9]$. These enzymes account for about $60 \%$ of the total enzyme market [10-12]. Microbial proteases are preferred to enzymes from plant and animal sources, since they possess almost all the characteristics desired for biotechnological applications [13]. Commercial proteases are mostly produced from various bacteria, and it was reported that about $35 \%$ of the total microbial enzymes used in detergent industry are the proteases from bacteria sources [14]. Among bacteria Bacillus sp. are specific producers of extracellularly proteases [15] and can be cultivated under extreme temperature and $\mathrm{pH}$ conditions to give rise to products that are, in turn, stable in a wide range of harsh environments [16]. Furthermore, many Bacillus sp. secrete large amounts of proteases than that required for their physiological activities [17]. The cost of enzyme production is a major obstacle in its successful industrial application [18], so it should be produced in high yields in a low-cost medium.

In the present study we report the isolation of alkaline protease producer Bacillus sp. strain CR-179, from soil sample of Lavizan jungle park, and then focus on optimizing the production of extracellular protease by testing various environmental and nutritional factors.

\section{Materials and Methods}

2.1. Microorganism. Soil samples were taken from Tehran jungle parks included Lavizan, Chitgar, Sorhke hesar, Taleghani, and Khojr. The isolated bacteria were inoculated 
on to skim milk agar plates and incubated at $37^{\circ} \mathrm{C}$ for $24-$ $72 \mathrm{~h}$. Appearance of clearing zones formed by hydrolysis of skim milk revealed the capability of bacteria for producing protease. The protease producers were then subcultured on to nutrient agar plates in order to obtain pure isolates of bacteria species. The resulting isolated colonies were subcultured on to nutrient agar slants, grown at $37^{\circ} \mathrm{C}$ for $24 \mathrm{~h}$, maintained at $4^{\circ} \mathrm{C}$, and subcultured at four-week intervals. They were identified as Bacillus species based on gram staining, cellular morphology, and some biochemical tests. Genetical analysis was also done for one of the species. For sequencing analysis, the genomic DNA was extracted from the isolate, using Roche kit. The amplification of the16S rDNA was performed through PCR technique, using Taq DNA polymerase, genomic DNA as a template, and $3^{\prime}$ forward and $5^{\prime}$ reverse universal primers. The primers used have nucleotide sequence as

\section{$3 \mathrm{f:} 5^{\prime}$ - AGAGTTTGATCCTGGC-3', 5 r: $5^{\prime}$ - TACCTTGTTACGACTT-3'.}

PCR products were sent to SQ lab Co. (Germany). By receiving the results, the $16 \mathrm{~S}$ rDNA nucleotide sequence of isolate has been deposited in GenBank and aligned with the $16 \mathrm{~S}$ rRNA sequences available in nucleotide database in NCBI, (National Center for Biotechnology Information, Available at: http://www.ncbi.nlm.nih.gov/), using BLAST software, (Basic Local Alignment Search Tool) [19].

2.2. Protease Production. The culture medium used in this work for protease production contained $(\mathrm{g} / \mathrm{L}$ of distilled water): corn steep liquor 4.0, starch $10.0, \mathrm{KCl} 0.3, \mathrm{MgSO}_{4}$ $0.5, \mathrm{~K}_{2} \mathrm{HPO}_{4} 0.87$, and $\mathrm{CaCl}_{2}$ 0.29. The $\mathrm{pH}$ was adjusted to 7.0-8 with $1 \% \mathrm{Na}_{2} \mathrm{CO}_{3}$, and this medium was sterilized by autoclaving at $121^{\circ} \mathrm{C}$ for $15 \mathrm{~min}$. The above medium $(50 \mathrm{~mL}$ in $250 \mathrm{~mL}$ Erlenmeyer flasks) was inoculated with $1 \mathrm{~mL}$ of an overnight culture and incubated at $45^{\circ} \mathrm{C}$ in a rotary shaker operated at $150 \mathrm{rpm}$ for $24 \mathrm{~h}$. At the end of fermentation period, the contents were centrifuged at $15500 \mathrm{~g}$ for $15 \mathrm{~min}$ at $4^{\circ} \mathrm{C}$, and the cell-free supernatant was used as crude enzyme for enzyme assay.

2.3. Protease Assay. The activity of protease was assessed in triplicate by measuring the release of trichloroacetic-acid soluble peptides from $0.5 \%(\mathrm{w} / \mathrm{v})$ casein in $50 \mathrm{mM}$ glycin $\mathrm{NaOH}(\mathrm{pH} 9.0)$ at $60^{\circ} \mathrm{C}$ for $10 \mathrm{~min}$. The $1 \mathrm{~mL}$ reaction was terminated by adding $0.5 \mathrm{~mL}$ of $10 \%$ trichloroacetic acid. It was left for $15 \mathrm{~min}$ and then centrifuged at $14000 \mathrm{~g}$ for $10 \mathrm{~min}$. One unit of enzyme activity was defined as the amount of enzyme required to release $1 \mu \mathrm{g}$ of tyrosine/min under standard conditions [20].

2.4. Effect of Culture Components on Protease Production. The effect of carbon sources $1 \%(\mathrm{w} / \mathrm{v})$ and nitrogen sources $0.4 \%(\mathrm{w} / \mathrm{v})$ on enzyme production was determined by growing the isolate in production media with different carbon and nitrogen sources. In this study various carbon sources such as glucose, galactose, maltose, lactose, starch, sucrose, and fructose were used. Sources of nitrogen included yeast extract, beef extract, corn steep liquor, whey protein, peptone, tryptone, and urea.

2.5. Effect of $\mathrm{pH}$ on Protease Production. The effect of $\mathrm{pH}$ on protease production was determined by growing the isolate in production media with an initial $\mathrm{pH}$ range of 6 to 10 using $1 \% \mathrm{Na}_{2} \mathrm{CO}_{3}$.

2.6. Effect of Agitation Rate on Protease Production. The effect of agitation rate on enzyme production was investigated by incubating culture flasks at different agitation speed of 110 , 130,150 , and $180 \mathrm{rpm}$.

2.7. Effect of $\mathrm{pH}$ on Protease Activity. The optimum $\mathrm{pH}$ for enzyme activity was determined with casein $0.5 \%(\mathrm{w} / \mathrm{v})$ as substrate dissolved in different buffers (sodium phosphate, pH 6-7, Tris-HCl, pH 8-9, and glycine $\mathrm{NaOH}, \mathrm{pH}$ 9-11).

2.8. Effect of Temperature on Protease Activity. The effect of temperature on enzyme activity was determined by performing the standard assay procedure at $\mathrm{pH} 9$ within a temperature range from $40^{\circ} \mathrm{C}$ to $75^{\circ} \mathrm{C}$.

\section{Results and Discussion}

Members of the genus Bacillus are widely used in industry in the large-scale production of enzymes, such as proteases. Of particular industrial importance are proteases with activity at alkaline $\mathrm{pH}$ and high temperature [21]. In the present study forty bacterial isolates were obtained from soil samples of which eighteen isolates were identified as proteolytic Bacillus species based on gram staining, cellular morphology, and some biochemical tests such as lecithin, gelatin, and casein hydrolysis in which all the species were positive in these tests. The proteolytic activity was assayed using skim milk agar and expressed as diameter of clear zones in $\mathrm{mm}$. One of the Bacillus isolated from Lavizan jungle park (L7) exhibited the highest proteolytic activity with a clear zone diameter of $55 \mathrm{~mm}$ after $72 \mathrm{~h}$, although other isolates from soil samples of Khojir and Chitgar parks exhibited clear zone diameter of 45 and $40 \mathrm{~mm}$, respectively. Figure 1 compares clear zones of proteolytic Bacillus species from different soil samples on skim milk agar.

The isolate L7 was selected for further experimental studies in order to optimize the production of protease. The BLAST search of $16 \mathrm{~S}$ rRNA gene sequence against sequences in nucleotide database has shown 97\% homology with Bacillus sp. strain CR-179 16S rRNA gene sequence with accession number of AJ82128.

3.1. Culture Conditions for Enzyme Production. Figure 2 reports the time course of protease production by Bacillus sp. strain CR-179 in liquid medium containing starch (1\%) as carbon source and corn steep liquor $(0.4 \%)$ in $250 \mathrm{~mL}$ erlenmeyer flasks. The formation of protease significantly started from early stationary phase and reached a maximum in $24 \mathrm{~h}$, with levels of $340.980 \mathrm{U} / \mathrm{mL}$ and then began to fall. In a similar study maximum protease activity was 


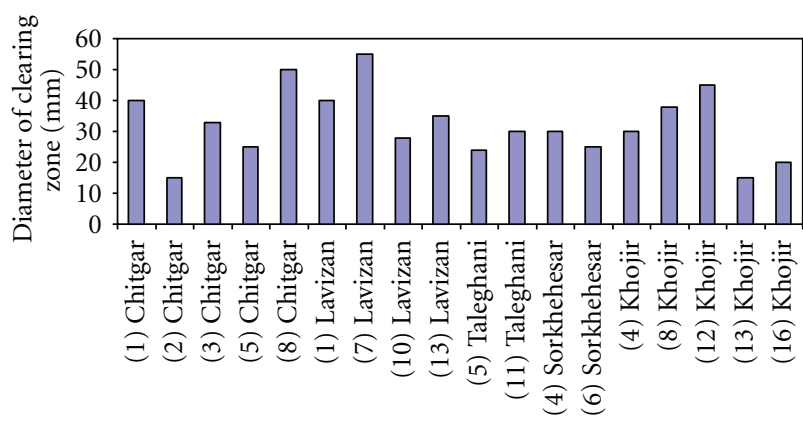

Proteolytic Bacillus species

FIGURE 1: Diameter of the clear zones of proteolytic Bacillus species on skim milk agar.

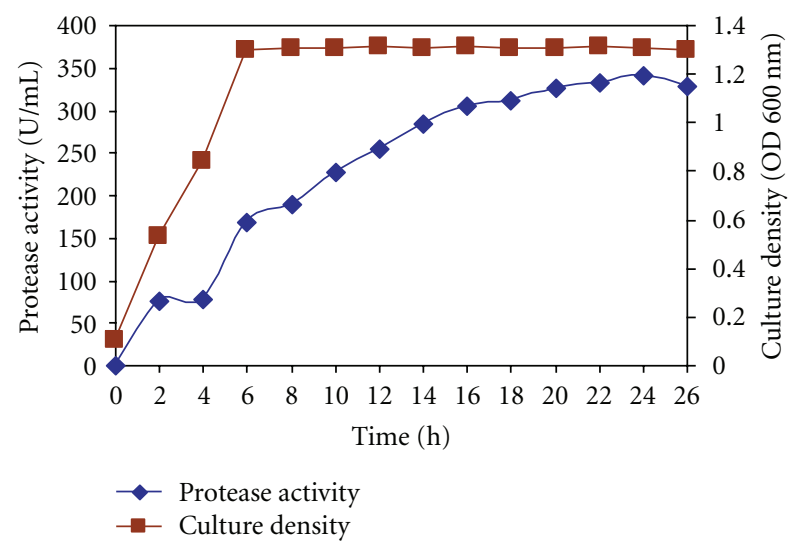

Figure 2: Protease production as a function of cultivation time by Bacillus sp. strain CR-179 grown on starch (1\%) and corn steep liquor $(0.4 \%)$ in shake flasks at initial $\mathrm{pH} 8$ and at $45^{\circ} \mathrm{C}$.

determined at the 18th hour, which occurred in the late stationary phase, when most of the bacteria sporulated [22]. Bacillus sp. are spore-forming bacteria; thus during sporulation and also germination, it increases protease activity [23]. Scientists acclaimed that during sporulation and germination, hydrolyzed proteins were used to compose proteins for endospores or vegetative cells $[24,25]$. This process requires an increase of protease production. This is in contrast to previous report which showed that Bacillus sp. usually produce more protease during the late exponential phase [26]. Another investigation done by Asokan, S. and Jayanthi, C. [27] revealed different results; they observed that the optimum incubation time for enzyme production is 96 hours.

In an earlier investigation maximum activity of protease was attained after 48 hours of fermentation, after which the activity started to decline [28].

Using of cost-effective growth medium for the production of alkaline proteases from an alkalophilic Bacillus sp. is especially important [20]. Therefore, there is a need to find new strains of bacteria with the ability of producing proteolytic enzymes with novel properties and the development of low-cost media. The present investigation was aimed at optimization of medium components which have
TABLE 1: Effect of carbon source on Bacillus sp. strain CR-179 growth and protease activity. The culture density and extracellular protease activity determined during $24 \mathrm{~h}$ incubation at $45^{\circ} \mathrm{C}$ and initial $\mathrm{pH} 8$.

\begin{tabular}{lcc}
\hline Carbon source & $\begin{array}{c}\text { Culture density } \\
(\text { OD } 600 \mathrm{~nm})\end{array}$ & $\begin{array}{c}\text { Maximum enzyme } \\
\text { activity }(\mathrm{U} / \mathrm{mL})\end{array}$ \\
\hline Starch & 1.428 & 337.532 \\
Lactose & 1.322 & 229.740 \\
Fructose & 1.125 & 76.493 \\
Galactose & 1.512 & 297.272 \\
Maltose & 1.620 & 303.766 \\
Glucose & 1.121 & 52.597 \\
Sucrose & 1.117 & 49.740 \\
\hline
\end{tabular}

TABle 2: Effect of nitrogen source on Bacillus sp. strain CR-179 growth and protease activity. The culture density and extracellular protease activity were determined during $24 \mathrm{~h}$ incubation at $45^{\circ} \mathrm{C}$ and at initial $\mathrm{pH} 8$.

\begin{tabular}{lcc}
\hline Nitrogen source & $\begin{array}{c}\text { Culture density } \\
(\text { OD } 600 \mathrm{~nm})\end{array}$ & $\begin{array}{c}\text { Maximum enzyme } \\
\text { activity }(\mathrm{U} / \mathrm{mL})\end{array}$ \\
\hline Corn steep liquor & 1.410 & 336.233 \\
Whey protein & 1.114 & 239.870 \\
Beef extract & 1.383 & 203.246 \\
Yeast extract & 1.391 & 308.961 \\
Tryptone & 0.954 & 190 \\
Peptone & 1.030 & 119.350 \\
Urea & 0.666 & 46.883 \\
\hline
\end{tabular}

been predicted to play a significant role in enhancing the production of alkaline proteases [29]. Bacillus sp. strain CR179 was capable of using a wide range of carbon sources, but production of protease varied according to each carbon source (Table 1). In the present study starch was the best substrate for enzyme production, followed by maltose, while glucose, fructose, and sucrose were less effective. Moderate to good amount of protease activity was produced in the presence of lactose and galactose. This is in agreement with previous report which showed that starch caused high level of enzyme expression in Bacillus species [30]. But this is in contrast to a recent report which showed that maltose and starch caused low protease production [31].

Utilization of maltose and galactose was also shown to result in better growth than consuming starch, although starch was the best substrate for enzyme production. It suggests that optimum conditions for protease production are not necessarily the same as the best conditions for growth. This observation is in contrast to previous study done by Camila Rocha da Silva et al. They showed that starch was the best carbon source for both growth and protease production [32].

Organic nitrogen sources such as corn steep liquor, beef extract, yeast extract, whey protein, tryptone, and peptone were tested on the growth and protease production of Bacillus sp. (Table 2). 
TABLE 3: Effect of $\mathrm{pH}$ on growth and protease activity by Bacillus sp. strain CR-179 cultivated in a liquid medium containing starch (1\%) and corn steep liquor $(0.4 \%)$ in shake flasks during $24 \mathrm{~h}$ at $45^{\circ} \mathrm{C}$.

\begin{tabular}{lcc}
\hline Initial $\mathrm{pH}$ & $\begin{array}{c}\text { Culture density } \\
(\text { OD 600 nm) }\end{array}$ & $\begin{array}{c}\text { Maximum enzyme } \\
\text { activity }(\mathrm{U} / \mathrm{mL})\end{array}$ \\
\hline 6 & 0.980 & 168.18 \\
7 & 1.335 & 260.129 \\
8 & 1.402 & 335.454 \\
9 & 1.012 & 253.37 \\
10 & 0.734 & 163.506 \\
\hline
\end{tabular}

Results obtained revealed that corn steep liquor, which is commercial, led to both maximum protease production and growth. So by using corn steep liquor in the growth medium, the production cost of the enzyme can be lessened. In some organisms, however, organic nitrogen sources were found to be better nitrogen sources both for growth and also protease production $[33,34]$. In a similar study Singh et al. used cheap nitrogen sources such as corn steep liquor for the production of a thermostable acid protease by a strain of Aspergillus niger F2078 [35]. Although in this study other organic nitrogen sources such as yeast extract, beef extract, and whey protein could result in good amount of enzyme production, they were less effective than corn steep liquor. This finding is in contrast to Shafee et al. They found beef extract as the best substrate for protease production [30]. In an earlier report Uyar et al. found skim milk to have significant effect on the production of the extracellular protease [36].

Protease activity varied with initial $\mathrm{pH}$ of the culture medium (Table 3 ). The highest levels of protease activity were detected in the cultures grown at $\mathrm{pH} 8$. The growth was the highest at $\mathrm{pH} 8$ too. It suggests that Bacillus sp. strain CR179 can be classified as alkaliphilic Bacilli, since alkaliphiles are defined as organisms that grow optimally at alkaline $\mathrm{pH}$, with $\mathrm{pH}$ optima for growth being in excess of $\mathrm{pH} 8$ and some being capable of growing at $\mathrm{pH}>11[37,38]$. In a similar study Das and Prasad considered the $\mathrm{pH}$ of 8.0 as the best $\mathrm{pH}$ for protease production [39].

Microorganisms vary in their oxygen requirement. In particular, $\mathrm{O}_{2}$ acts as a terminal electron acceptor for oxidative reactions to provide energy for cellular activities. The variation in the agitation speed has been found to influence the extent of mixing in the shake flasks and also affect the nutrient availability [40]. Agitation rates have been shown to affect protease in various strains of bacteria $[41,42]$. In the present investigation, Bacillus sp. strain CR-179 grown in culture media containing starch and corn steep liquor showed maximum protease activity at $150 \mathrm{rpm}$ agitation speed after $24 \mathrm{~h}$ incubation (Table 4 ). At this speed, aeration of the culture medium was increased which could lead to sufficient supply of dissolved oxygen in the media [43]. Nutrient uptake by bacteria also will be increased [44] resulting in increased protease production. At $180 \mathrm{rpm}$ pro-tease activity was found to be reduced. This was perhaps due to denaturation of enzymes caused by high agitation speed [45]. High agitation rates could also damage bacterial
TABLE 4: Effect of agitation rate on growth and protease activity by Bacillus sp. strain CR-179 cultivated in a liquid medium containing starch (1\%) and corn steep liquor (0.4\%) in shake flasks during $24 \mathrm{~h}$ at $45^{\circ} \mathrm{C}$.

\begin{tabular}{lcc}
\hline $\begin{array}{l}\text { Agitation rate } \\
(\mathrm{rpm})\end{array}$ & $\begin{array}{c}\text { Culture density } \\
(\text { OD } 600 \mathrm{~nm})\end{array}$ & $\begin{array}{c}\text { Maximum enzyme } \\
\text { activity }(\mathrm{U} / \mathrm{mL})\end{array}$ \\
\hline 110 & 1.327 & 301.688 \\
130 & 1.388 & 320.389 \\
150 & 1.418 & 345.844 \\
180 & 1.330 & 307.142 \\
\hline
\end{tabular}

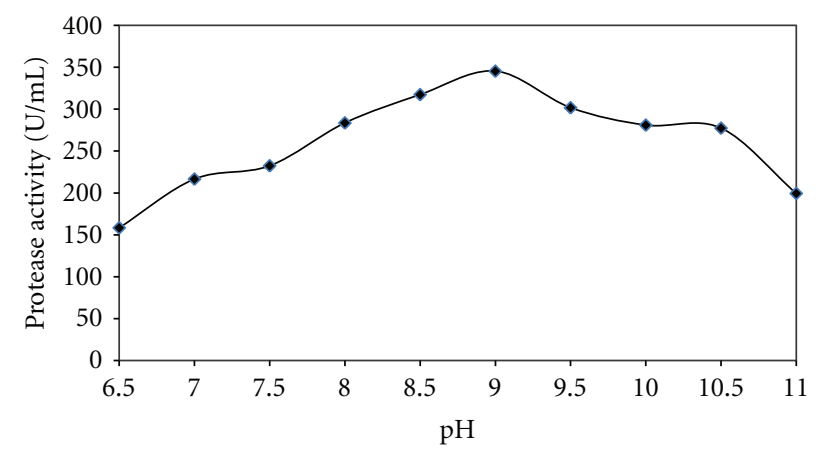

FIgure 3: Optimum pH profile of the Bacillus sp. strain CR-179 protease grown at $45^{\circ} \mathrm{C}$ for $24 \mathrm{~h}$.

cells, so that reduction of protease producers will result in decreased protease production. Agitation speed of 110 and $130 \mathrm{rpm}$ affected the growth of the organism considerably. At this agitation rates, insufficient aeration and nutrient uptake perhaps caused the inability of bacteria to grow efficiently. In a similar study a notable increase in the protease production with the high agitation rate $(>200 \mathrm{rpm})$ was reported. It was also revealed that a decrease in agitation rate drastically lowered the total protease yield [46].

3.2. Effect of $p H$ on Protease Activity. From an industrial prospective, the protease must exhibit considerable activity at high $\mathrm{pH}(\mathrm{s})$ and temperature (s). A pH range between 6.5 and 11.0 was used to study the effect of $\mathrm{pH}$ on protease activity (Figure 3 ). The crude protease had a relatively wide $\mathrm{pH}$ range between 8.0 to 10.5 , with maximum enzyme activity at $\mathrm{pH}$ 9.0. Proteases that have $\mathrm{pH}$ optima in the range of $8.0-11.0$ are grouped under the category of alkaline proteases [4749]. Maximum activity at pH 9.0 indicates the enzyme to be alkaline protease. Hence this protease can be introduced as an industrially and economically feasible enzyme. In a similar study Ibrahim et al. found an alkaline protease which had maximum activity at $\mathrm{pH} 10.0$ [50].

3.3. Effect of Temperature on Protease Activity. The protease activities were assayed at different temperatures ranging from $40^{\circ} \mathrm{C}$ to $70^{\circ} \mathrm{C}$ at a constant $\mathrm{pH}$ of 9.0 (Figure 4). Enzyme activity increased with temperature within the range of $40^{\circ} \mathrm{C}$ to $60^{\circ} \mathrm{C}$ and showed reasonable activity at temperature range of $50^{\circ} \mathrm{C}-65^{\circ} \mathrm{C}$, with maximum activity at $60^{\circ} \mathrm{C}$. A reduction in enzyme activity was observed at values above 


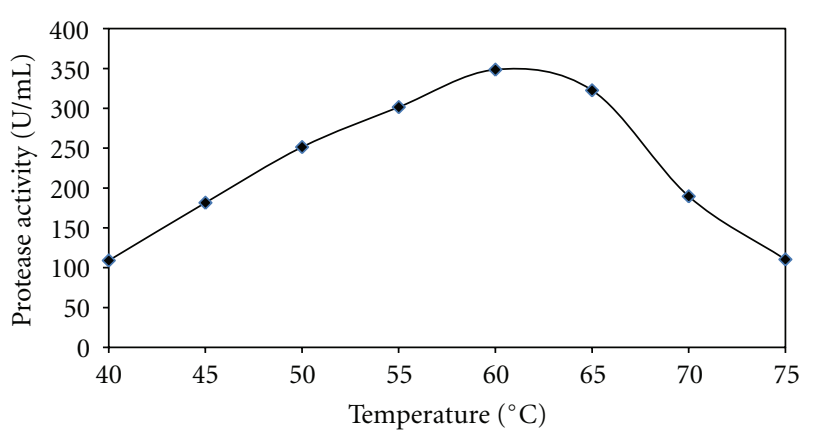

FIgURE 4: Temperature profile of the Bacillus sp. strain CR-179 protease grown at $45^{\circ} \mathrm{C}$ for $24 \mathrm{~h}$.

$60^{\circ} \mathrm{C}$. Maximum activity at $60^{\circ} \mathrm{C}$ indicates the enzyme to be thermoprotease. This observation was similar to the report of Nascimento et al. They worked on a thermophilic Bacillus sp. which produced a protease with maximum activity at $60^{\circ} \mathrm{C}$ [40]. Maximum protease activity at high temperatures is a very suitable characteristic for its industrial acceptability.

\section{Conclusion}

In the present investigation we report the isolation of proteolytic Bacilli from Tehran jungle parks. As the characterization and optimization for each factor of growth, nutritional requirement, and production yields are essential requirements before the selected strain is used for further investigation, the yield improvement of alkaline protease, in general by any microbial system, depends on the physiological, nutritional, and biochemical nature of the microbe employed, and these factors vary from organism to organism [14, 51-53]; one of the strongest isolates, Bacillus sp. strain CR-179, was selected in order to optimize the culture conditions for protease production. Scientists preferred studying new isolates because they could be alternative for commercial use [54-56]. This strain can be used for largescale production of alkaline protease to meet the present day demand of the industrial applications. Starch and corn steep liquor are cheap carbon and nitrogen sources which led us to propose a low-cost medium formulation for maximum protease production. Major industrial units are continuously trying to identify enzymes that have potential industrial applications, either to use them correctly or to create popular enzymes with enhanced catalytic activity for well-adapted large-scale industrial processes [57]. The optimum $\mathrm{pH}$ and temperature for enzyme activity were determined as 9.0 and $60^{\circ} \mathrm{C}$, respectively. As the thermoactivity and $\mathrm{pH}$ stability of proteases are of great importance in industrial uses, enzymatic properties indicate the potential use of this bacterium and its protease for various industrial applications.

\section{Acknowledgment}

The authors thank the laboratory complex of Sciences and Researches campus of Islamic Azad University for providing the laboratorial equipment.

\section{References}

[1] F. W. J. L. Maase and R. van Tilburg, "The benefit of detergent enzymes under changing washing conditions," Journal of the American Oil Chemists Society, vol. 60, no. 9, pp. 1672-1675, 1983.

[2] A. M. Wolff, M. S. Showell, M. G. Venegas, B. L. Barnett, and W. C. Wertz, "Laundry performance of subtilisin proteases," in Subtilisin Enzymes: Practical Protein Engineering, R. Bolt and C. Betzel, Eds., pp. 113-120, Plenum Press, New York, NY, USA, 1993.

[3] S. J. Ainsworth, "Soaps \& detergents," Chemical and Engineering News, vol. 72, no. 4, pp. 34-59, 1994.

[4] H. Outtrup, C. Dambmann, M. D. Christiansen, and A. Aaslyng, "Bacillus sp. JP 395, method of making and detergent composition," US patent no 5466594, 1995.

[5] D. A. Inhs, W. Schmidt, and F. R. Richter, "Proteolytic enzyme cleaner," US patent no. 5961366, 1998.

[6] K. Adinarayana and P. Ellaiah, "Response surface optimization of the critical medium components for the production of alkaline protease by a newly isolated Bacillus sp," Journal of Pharmacy and Pharmaceutical Sciences, vol. 5, no. 3, pp. 272$278,2002$.

[7] N. Fujiwara, K. Yamamoto, and A. Masui, "Utilization of a thermostable alkaline protease from an alkalophilic thermophile for the recovery of silver from used X-ray film," Journal of Fermentation and Bioengineering, vol. 72, no. 4, pp. 306308, 1991.

[8] M. D. Pastor, G. S. Lorda, and A. Balatti, "Protease obtention using Bacillus subtilis 3411 and amaranth seed meal medium at different aeration rates," Brazilian Journal of Microbiology, vol. 32 , no. 1 , pp. $1-8,2001$.

[9] H. S. Joo and C. S. Chang, "Production of protease from a new alkalophilic Bacillus sp. I-312 grown on soybean meal: optimization and some properties," Process Biochemistry, vol. 40, no. 3-4, pp. 1263-1270, 2005.

[10] J. G. Zeikus, C. Vieille, and A. Savchenko, "Thermozymes: biotechnology and structure-function relationships," Extremophiles, vol. 1, pp. 2-13, 1998.

[11] A. S. Nunes and M. L. L. Martins, "Isolation, properties and kinetics of growth of a thermophilic Bacillus," Brazilian Journal of Microbiology, vol. 32, no. 4, pp. 271-275, 2001.

[12] J. Singh, N. Batra, and R. C. Sobti, "Serine alkaline protease from a newly isolated Bacillus sp. SSR1," Process Biochemistry, vol. 36, no. 8-9, pp. 781-785, 2001.

[13] K. Rao and M. L. Narasu, "Alkaline protease from Bacillus firmus 7728," African Journal of Biotechnology, vol. 6, no. 21, pp. 2493-2496, 2007.

[14] M. A. Ferrero, G. R. Castro, C. M. Abate, M. D. Baigori, and F. Siñeriz, "Thermostable alkaline proteases of Bacillus licheniformis MIR 29: isolation, production and characterization," Applied Microbiology and Biotechnology, vol. 45, no. 3, pp. 327332, 1996

[15] F. G. Priest, "Extracellular enzyme synthesis in the genus $B a-$ cillus," Bacteriological Reviews, vol. 41, no. 3, pp. 711-753, 1977.

[16] X. Q. Han and S. Damodaran, "Isolation, identification, and fermentation of a Bacillus species producing a detergent-stable endopeptidase," Journal of Agricultural and Food Chemistry, vol. 45, no. 11, pp. 4191-4195, 1997.

[17] S. H. Bhosale, M. B. Rao, V. V. Deshpande, and M. C. Srinivasan, "Thermostability of high-activity alkaline protease from Conidiobolus coronatus (NCL 86.8.20)," Enzyme and Microbial Technology, vol. 17, no. 2, pp. 136-139, 1995. 
[18] S. F. G. Oskouie, F. Tabandeh, B. Yakhchali, and F. Eftekhar, "Response surface optimization of medium composition for alkaline protease production by Bacillus clausii," Biochemical Engineering Journal, vol. 39, no. 1, pp. 37-42, 2008.

[19] P. F. Lyon, T. Beffa, M. Blanc, G. Auling, and M. Aragno, "Isolation and characterization of highly thermophilic xylanolytic Thermus thermophilus strains from hot composts," Canadian Journal of Microbiology, vol. 46, no. 11, pp. 1029-1035, 2000.

[20] H. S. Joo, C. G. Kumar, G. C. Park, K. T. Kim, S. R. Paik, and C. S. Chang, "Optimization of the production of an extracellular alkaline protease from Bacillus horikoshii," Process Biochemistry, vol. 38, no. 2, pp. 155-159, 2002.

[21] A. S. de Boer, F. Priest, and B. Diderichsen, "On the industrial use of Bacillus licheniformis: a review," Applied Microbiology and Biotechnology, vol. 40, no. 5, pp. 595-598, 1994.

[22] K. Özgür and C. Nilüfer, "Isolation of protease producing novel Bacillus cereus and detection of optimal conditions," African Journal of Biotechnology, vol. 10, no. 7, pp. 1160-1164, 2011.

[23] N. Cihangir and N. Ve Aksöz, "Bacillus sp. proteazının sentezi ve etkili bazı kültürel parametrelerinin saptanması,” Kükem Dergisi, vol. 11, pp. 27-34, 1998.

[24] L. Prestidge, V. Gage, and J. Spizizen, "Protease activities during the course of sporulation on Bacillus subtilis," Journal of Bacteriology, vol. 107, no. 3, pp. 185-213, 1971.

[25] W. James and J. Mandelstam, "Protease production during sporulation of germination mutants of Bacillus subtilis and the cloning of a functional gerE gene," Journal of General Microbiology, vol. 131, no. 9, pp. 2421-2430, 1985.

[26] O. P. Ward, "Proteolytic enzymes," in Comprehensive Biotechnology, M. Moo-Young, Ed., vol. 3, pp. 789-818, 1985.

[27] S. Asokan and C. Jayanthi, "Alkaline protease production by Bacillus licheniformis and Bacillus coagulans," Journal of Cell Tissue Research, vol. 10, no. 1, pp. 2119-2123, 2010.

[28] M. A. Khan, N. Ahmad, A. U. Zafar, I. A. Nasir, and M. A. Qadir, "Isolation and screening of alkaline protease producing bacteria and physio-chemical characterization of the enzyme," African Journal of Biotechnology, vol. 10, no. 33, pp. 62036212, 2011.

[29] R. Gupta, Q. Beg, S. Khan, and B. Chauhan, "An overview on fermentation, downstream processing and properties of microbial alkaline proteases," Applied Microbiology and Biotechnology, vol. 60, no. 4, pp. 381-395, 2002.

[30] N. Shafee, S. Norariati Aris, R. Noor Zaliha Abd Rahman, M. Basri, and A. Salleh, "Optimization of environmental and nutritional conditions for the production of alkaline protease by a newly isolated bacterium Bacillus cereus strain 146," Journal of Applied Sciences Research, vol. 1, no. 1, pp. 1-8, 2005.

[31] R. Bhatiya and G. R. Jadeja, "Optimization of environmental and nutritional factors for alkaline protease production," Electronic Journal of Environmental, Agricultural and Food Chemistry, vol. 9, no. 3, pp. 594-599, 2010.

[32] C. R. da Silva, A. B. Delatorre, and M. L. L. Martins, "Effect of the culture conditions on the production of an extracellular protease by thermophilic Bacillus sp and some properties of the enzymatic characterization," Brazilian Journal of Microbiology, vol. 38, no. 2, pp. 253-258, 2007.

[33] P. Aleksieva, A. Djerova, B. Tchorbanov, and I. Grigorov, "Submerged cultivation of a strain of Humicola lutea 72 producing acid protease," European Journal of Applied Microbiology and Biotechnology, vol. 13, no. 3, pp. 165-169, 1981.

[34] S. U. Phadatare, V. V. Deshpande, and M. C. Srinivasan, "High activity alkaline protease from Conidiobolus coronatus (NCL
86.8.20): enzyme production and compatibility with commercial detergents," Enzyme and Microbial Technology, vol. 15, no. 1, pp. 72-76, 1993.

[35] A. Singh, V. K. Ghosh, and P. Ghosh, "Production of thermostable acid protease by Aspergillus niger," Letters in Applied Microbiology, vol. 18, no. 3, pp. 177-180, 1994.

[36] F. Uyar, I. Porsuk, G. Kizil, and E. Yilmaz, "Optimal conditions for production of extracellular protease from newly isolated Bacillus cereus strain CA15," EurAsian Journal of BioSciences, vol. 5, pp. 1-9, 2011.

[37] K. Horikoshi, "Alkaliphiles: some applications of their products for biotechnology," Microbiology and Molecular Biology Reviews, vol. 63, no. 4, pp. 735-750, 1999.

[38] W. D. Grant and B. E. Jones, "Alkaline environments," in Encyclopaedia of Microbiology, J. Lederberg, Ed., vol. 1, pp. 126133, Academic Press, New York, NY, USA, 2nd edition, 2000.

[39] G. Das and M. P. Prasad, "Isolation, purification and mass production of protease enzyme from bacillus subtilis," International Research Journal of Microbiology, vol. 1, no. 2, pp. 026031, 2010.

[40] W. C. A. Nascimento and M. L. L. Martins, "Production and properties of an extracellular protease from thermophilic $B a$ cillus sp," Brazilian Journal of Microbiology, vol. 35, no. 1-2, pp. 91-96, 2004.

[41] H. Pourrat, C. Barthomeuf, O. Texier, and A. Pourrat, "Production of semi-alkaline protease by Aspergillus niger," Journal of Fermentation Technology, vol. 66, no. 4, pp. 383-388, 1988.

[42] S. S. Mabrouk, A. M. Hashem, N. M. A. El-Shayeb, A. M. S. Ismail, and A. F. Abdel-Fattah, "Optimization of alkaline protease productivity by Bacillus licheniformis ATCC 21415," Bioresource Technology, vol. 69, no. 2, pp. 155-159, 1999.

[43] C. G. Kumar and H. Takagi, "Microbial alkaline proteases: from a bioindustrial viewpoint," Biotechnology Advances, vol. 17, no. 7, pp. 561-594, 1999.

[44] Q. K. Beg, V. Sahai, and R. Gupta, "Statistical media optimization and alkaline protease production from Bacillus mojavensis in a bioreactor," Process Biochemistry, vol. 39, no. 2, pp. 203209, 2003.

[45] L. P. Geok, C. N. A. Razak, R. N. Z. Abd Rahman, M. Basri, and A. B. Salleh, "Isolation and screening of an extracellular organic solvent-tolerant protease producer," Biochemical Engineering Journal, vol. 13, no. 1, pp. 73-77, 2003.

[46] S. Saurabh, I. Jasmine, G. Pritesh, and S. Rajendra Kumar, "Enhanced productivity of serine alkaline protease by Bacillus sp. using soybean as Substrate," Malaysian Journal of Microbiology, vol. 3, no. 1, pp. 1-6, 2007.

[47] A. Hameed, M. A. Natt, and C. S. Evans, "Short communication: production of alkaline protease by a new Bacillus subtilis isolate for use as a bating enzyme in leather treatment," World Journal of Microbiology and Biotechnology, vol. 12, no. 3, pp. 289-291, 1996.

[48] H. Lee, D. B. Suh, J. H. Hwang, and H. J. Suh, "Characterization of a keratinolytic metalloprotease from Bacillus sp. SCB3," Applied Biochemistry and Biotechnology, vol. 97, no. 2, pp. 123-133, 2002.

[49] X. M. Tang, W. Shen, F. M. Lakay et al., "Cloning and overexpression of an alkaline protease from Bacillus licheniformis," Biotechnology Letters, vol. 26, no. 12, pp. 975-979, 2004.

[50] A. S. S. Ibrahim, N. M. A EI-Shayeb, and S. Mabrouk, "Isolation and identification of Alkaline protease Producing Alkaliphilic bacteria from an Egyptian soda lake," Journal of Applied Sciences Research, vol. 3, no. 11, pp. 1363-1368, 2007. 
[51] A. A. Kembhavi, A. Kulkarni, and A. Pant, "Salt-tolerant and thermostable alkaline protease from Bacillus subtilis NCIM No. 64," Applied Biochemistry and Biotechnology, vol. 28, pp. 409-413, 1993.

[52] B. Johnvesly and G. Naik, "Studies on production of thermostable alkaline protease from thermophilic and alkaliphilic Bacillus sp. JB-99 in a chemically defined medium," Process Biochemistry, vol. 37, no. 2, pp. 139-144, 2001.

[53] P. Ellaiah, B. Srinivasulu, and K. Adinarayana, "A review on microbial alkaline proteases," Journal of Scientific and Industrial Research, vol. 61, no. 9, pp. 690-704, 2002.

[54] S. Mehrotra, P. K. Pandey, R. Gaur, and N. S. Darmwal, "The production of alkaline protease by a Bacillus species isolate," Bioresource Technology, vol. 67, no. 2, pp. 201-203, 1999.

[55] S. Dube, L. Singh, and S. I. Alam, "Proteolytic anaerobic bacteria from lake sediments of Antarctica," Enzyme and Microbial Technology, vol. 28, no. 1, pp. 114-121, 2001.

[56] J. F. Hawumba, J. Theron, and V. S. Brözel, "Thermophilic protease-producing geobacillus from Buranga hot springs in western Uganda," Current Microbiology, vol. 45, no. 2, pp. 144 150, 2002.

[57] V. Glaser, "Steady growth for industrial enzyme market," Genetic Engineering-News, vol. 20, pp. 8-36, 2000. 

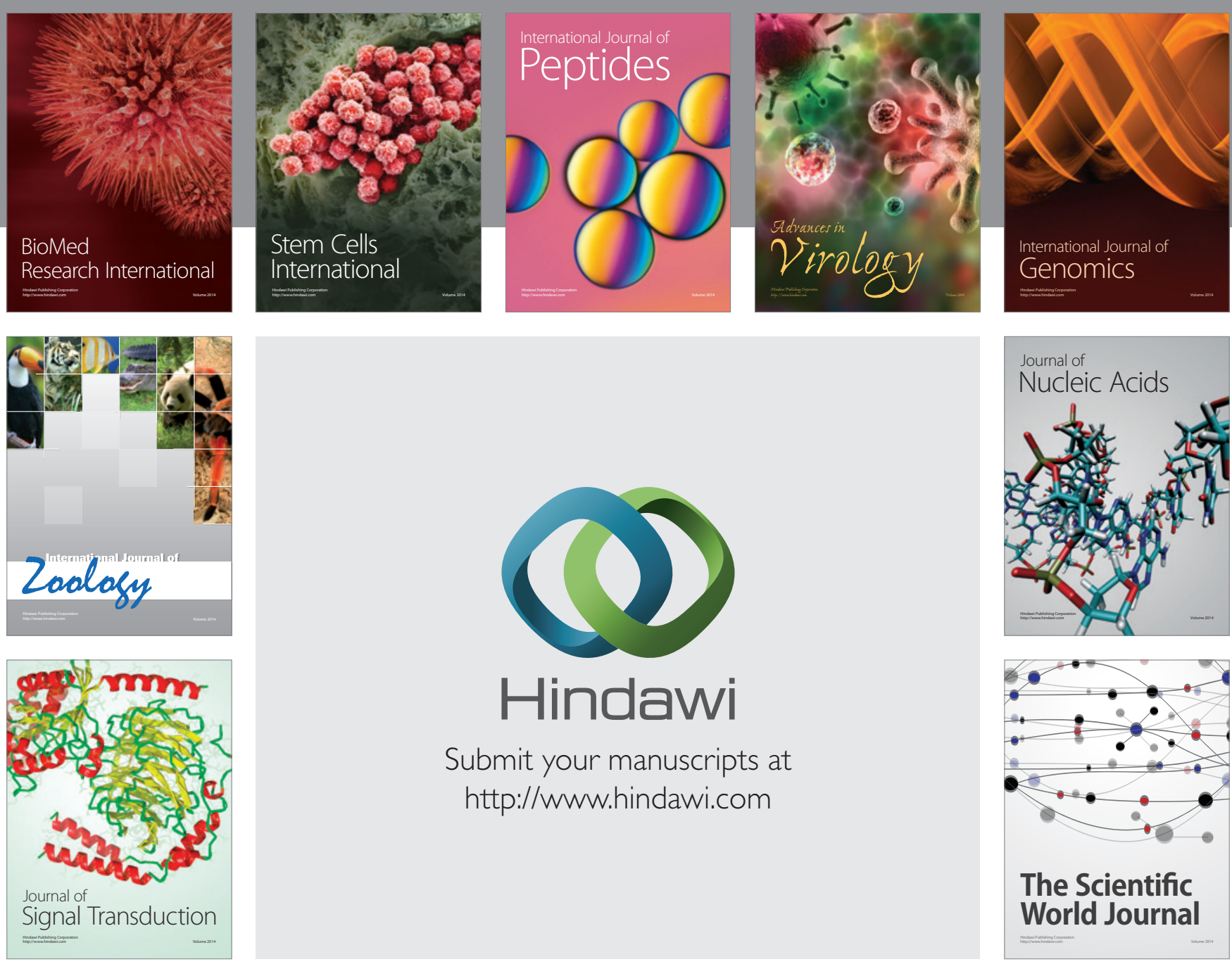

Submit your manuscripts at

http://www.hindawi.com
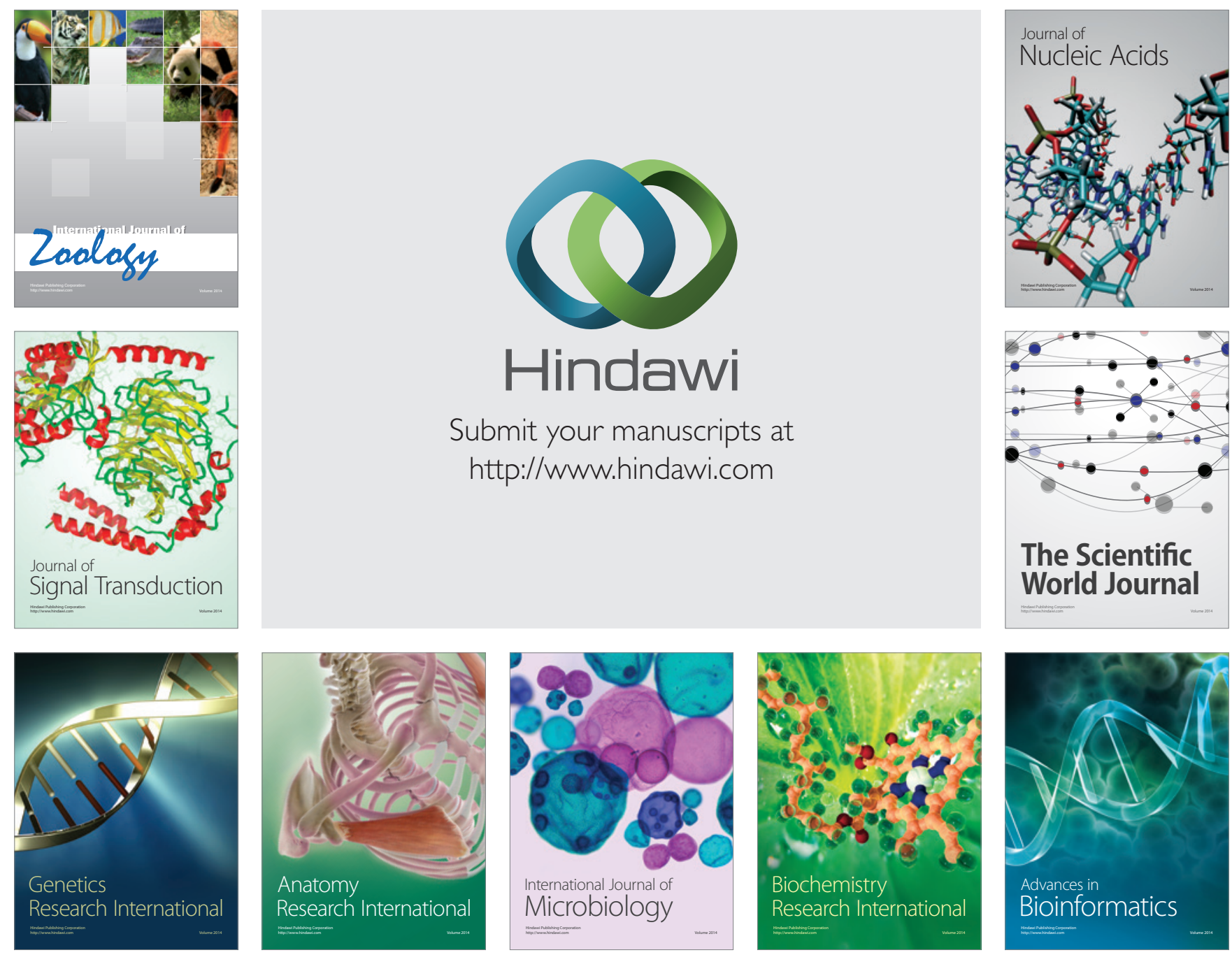

The Scientific World Journal
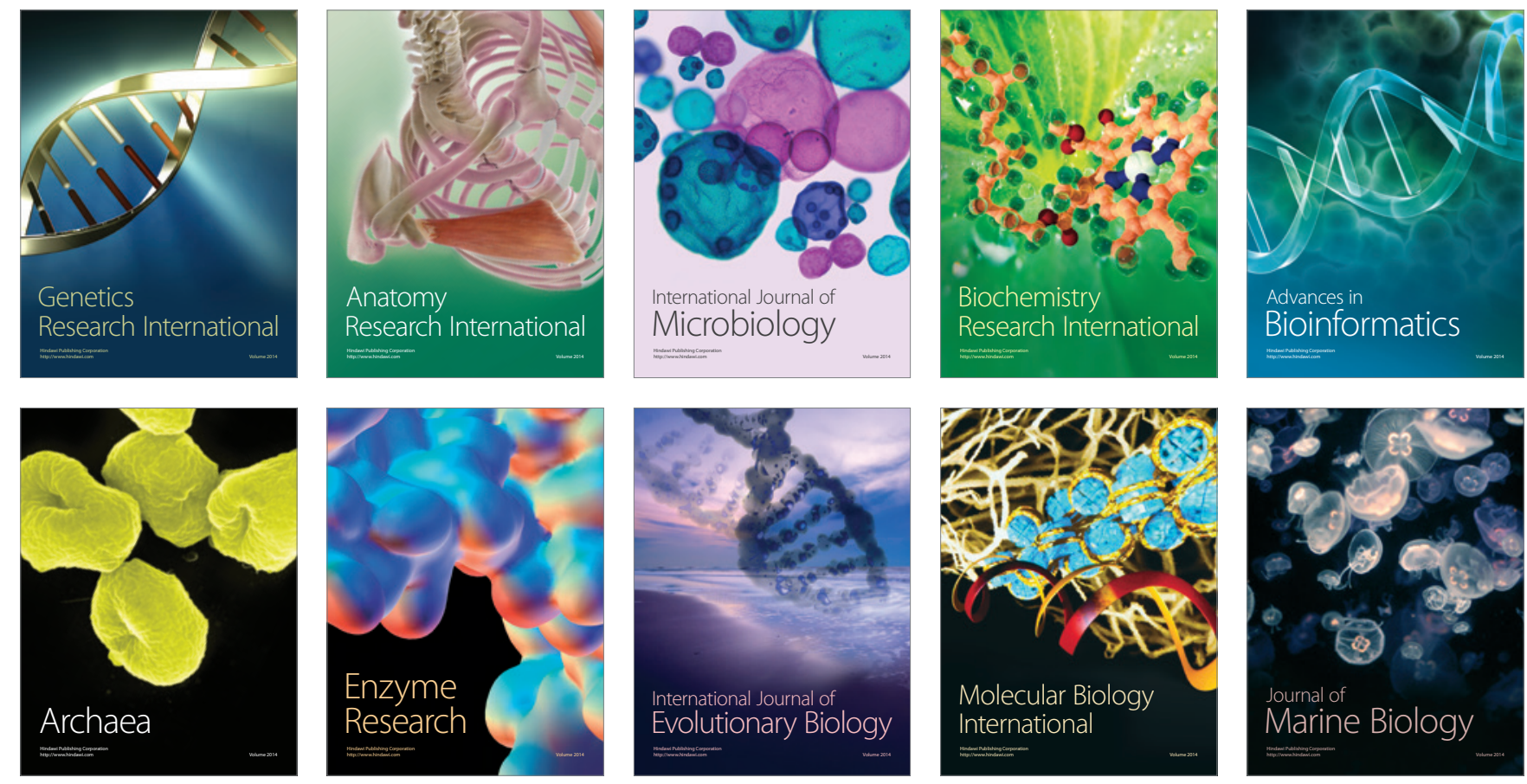